\title{
Manganese oxides from Zalas, Kraków area, southern Poland
}

\author{
Marta Polak, Bożena Gołębiowska, Grzegorz Rzepa \\ AGH University of Science and Technology, Faculty of Geology, Geophysics and Environmental Protection; \\ al. A. Mickiewicza 30, 30-059 Krakow, Poland; e-mail:polak.min@gmail.com \\ (C) 2016 Authors. This is an open access publication, which can be used, distributed and reproduced in any medium according \\ to the Creative Commons CC-BY 4.0 License requiring that the original work has been properly cited.
}

The Zalas quarry is located in the southern, marginal part of the Silesian-Cracovian Monocline. Permian rhyodacite laccolith has been exploited here for over 70 years. The intrusion was formed about 260-280 Ma during the Early Permian transtensional, sinistral tectonic regime predominating in central Europe at that time (Nawrocki et al. 2005). Permian volcanic rocks are overlain by a Middle-Upper Jurassic sedimentary sequence, built from sands and sandstones, substituted with the passing of time by limestones and sandy limestones rich in fossils (Matyszkiewicz et al. 2006).

Quarrying operations carried out approximately 10 years ago uncovered a fault zone cutting the Middle Jurassic sandy limestones. Exposed breccias was locally encrusted by a hydrothermal mineralization forming thin veinlets cutting the limestone, or surrounding the breccia clasts. Primary mineralization contained small relics of pyrite, chalcopyrite, chalcocite, galena, native bismuth and barite and was significantly replaced by supergene minerals e.g. Fe and Mn oxides, malachite, cuprite, $\mathrm{Cu}$ sulphates, iodargyrite, $\mathrm{Bi}$ oxychlorides and $\mathrm{Na}, \mathrm{K}$ chlorides (Gołębiowska et al. 2006, 2010, 2015). The mineralization is most likely connected with rejuvenation of Early-Paleozoic fault zones during the Sava phase of the Alpine orogeny, and subsequent intensive weathering under semi-arid and arid climate in a period between the Oligocene and Middle Miocene (Gołębiowska et al. 2010). In the sandy limestone encrusted by the oxidized mineralization, very interesting $\mathrm{Mn}$-oxides, enriched in numerous heavy metals were encountered. They filled small fractures and voids within the fault breccia. Among them, Tl-rich varieties have been recently reported. Extremely high thallium content, reaching $20.82 \mathrm{wt} \% \mathrm{Tl}_{2} \mathrm{O}$, makes the oxides unique on a world scale (Gołębiowska et al. 2015). In this paper we focused on the variable admixtures in Mn oxides from oxidation zone in Zalas; for this purpose, SEM-EDS and WDS analyses were carried out.

Mn oxides in Zalas are accompanied by malachite, Fe oxides (goethite and hematite) and relics of primary mineralization (Matyszkiewicz et al. 2015). Mn and Fe oxides commonly form the yellowish to red-brownish or black tiny grains or cryptocrystalline aggregates with sizes up to a few millimetres across.

Manganese oxides contain variable admixtures of $\mathrm{Cu}, \mathrm{Ca}, \mathrm{Pb}, \mathrm{Ba}, \mathrm{Fe}, \mathrm{Ni}, \mathrm{Co}$ and $\mathrm{Tl}$. On the basis of chemical analyses, three major Mn oxide types have been distinguished: those enriched in (i) $\mathrm{Ni}$ and $\mathrm{Co}$, (ii) $\mathrm{Pb}$ and (iii) $\mathrm{Ba}$ and $\mathrm{Ca}$.

Co-Ni-bearing $\mathrm{Mn}$ oxides, probably asbolane-type, contain 17.01-21.58 wt\% $\mathrm{CoO}$ and $3.05-8.33 \mathrm{wt} \% \mathrm{NiO}$. These phases contain also admixtures of $\mathrm{Cu}$ (up to $10 \mathrm{wt} \% \mathrm{CuO}$ ) and $\mathrm{Al}$ (up to $7 \mathrm{wt} \%$ of $\mathrm{Al}_{2} \mathrm{O}_{3}$ ), as well as traces of $\mathrm{Fe}, \mathrm{Ba}, \mathrm{Zn}, \mathrm{Mg}$ and $\mathrm{Tl}$ (up to $0.5 \mathrm{wt} \%$ ). Interestingly, in $\mathrm{Mn}$ oxides of this type, the admixtures of lead are absent. $\mathrm{Pb}$-bearing $\mathrm{Mn}$ oxide, probably coronadite, contain up to $21.48 \mathrm{wt} \% \mathrm{PbO}$. In its composition various other elements were also noticed: up to $2 \mathrm{wt} \%$ 
$\mathrm{CoO}, 0.4 \mathrm{wt} \% \mathrm{NiO}$ and very high concentrations of $\mathrm{CuO}$ up to $8 \mathrm{wt} \%$, as well as up to $1 \mathrm{wt} \% \mathrm{BaO}, \mathrm{FeO}$, $\mathrm{CaO} \mathrm{Tl}{ }_{2} \mathrm{O}, \mathrm{Al}_{2} \mathrm{O}_{3}$ and traces of $\mathrm{Zn}$ and $\mathrm{Mg}$. Chemical mapping indicates that the $\mathrm{Ba}$ - or $\mathrm{Ca}$-bearing Mn oxides occur only in marginal parts of zoned $\mathrm{MnO}_{2}$ aggregates with almost pure $\mathrm{MnO}_{2}$ in their cores. They contain $78-84 \mathrm{wt} \% \mathrm{MnO}_{2}, 3-10 \mathrm{wt} \%$ $\mathrm{BaO}$ and $2.5-4.5 \mathrm{wt} \% \mathrm{CaO}$.

High contents of $\mathrm{Co}, \mathrm{Ni}, \mathrm{Pb}, \mathrm{Cu}$ and $\mathrm{Tl}$ in $\mathrm{Mn}$ oxides from Zalas indicate a direct link with the primary ore assemblage. High concentration of cobalt and nickel might suggest some connection with $\mathrm{Co}$ and Ni mineralization known from nearby Karniowice Travertine (Czerny 1992). Mineral association, as well as crystal morphologies and sizes could indicate hydrothermal origin of at least part of the Mn oxides. However, identification of the particular minerals as well as concluding on the details of their origin is quite difficult on this stage of research.

This work was supported by the AGH UST grant no. 11.11.140.319.

\section{REFERENCES}

Czerny J., 1992. Hydrothermal mineralization phenomena in Karniowice Travertine near Cracow. Mineralogia Polonica, 23, 3-13.

Gołębiowska B., Rzepa G. \& Pieczka A., 2015. Extremely Tlrich manganese oxide from Zalas, Kraków area, southern Poland [in review].

Gołębiowska B., Matyszkiewicz J., Molenda R. \& Górny A., 2006. Hydrothermal mineralization in Middle Jurasic sandy limestones from Zalas (near Cracow, S Poland). Mineralogia Polonica, Special Papers 28, 81-83.

Gołębiowska B., Pieczka A., Rzepa G., Matyszkiewicz J. \& Krajewski M., 2010. Iodargyrite from Zalas (Cracow area, Poland) as an indicator of Oligocene-Miocene aridity in Central Europe. Palaeogeography, Palaeoclimatology, Palaeoecology, 296, 130-137.

Matyszkiewicz J., Krajewski M. \& Żaba J., 2006. Structural control on the distribution of Upper Jurassic carbonate buildups in the Kraków - Wieluń Upland (South Poland). Neues Jahrbuch für Geologie und Paläeontologie, Monatshefte, 3, 182-192.

Matyszkiewicz J., Kochman A., Gaidzik K., Rzepa G. Żaba J., Gołębiowska B. \& Krajewski M., 2015. Epigenetic silicification of Upper Oxfordian limestones in the Sokole Góry (Kraków-Częstochowa Upland): Relation to facies development and tectonics. Acta Geologica Polonica, 65, 181-203.

Nawrocki J., Polechońska O., Lewandowska A. \& Werner T., 2005. On the palaeomagnetic age of the Zalas laccolith (southern Poland). Acta Geologica Polonica, 55, 229-236. 